\title{
Channel Switching Behavior From Traditional Grocery Stores to Branded Grocery Chains in Karachi
}

\author{
Muhammad Mubin Jaliawala ${ }^{1}$ \\ Dr. Mustaghis-ur-Rahman ${ }^{2}$
}

\begin{abstract}
The advent of branded grocery chains has compelled customers to switch from traditional grocery stores to branded grocery chains or monthly grocery purchase. This phenomenon has been recently observed in Pakistan. The aim of this study is to explore the customers' level of switching over from traditional grocery stores to branded grocery chains and also to find out the determinants of switching over from traditional grocery stores to branded grocery chains in Karachi. This study is quantitative in nature and encompasses the Positivist paradigm. The deductive approach is employed and survey method is opted for in this research. As per the requirement of the theme, closed-ended questionnaire is used as research instrument and SPSS statistical software is employed for data analysis. As sampling strategy, convenience sampling technique is opted. Total of 105 valid questionnaires were received; 35 from each store i.e., Naheed Super Market, Imtiaz Super Store and Chaseup Departmental Store. To ascertain level of switching over it can be seen from the results that $90 \%$ of the respondents have been buying since four months and above from branded grocery chains. The research study reveals that the three independent variables (Proximity, Environment and Engagement) are correlated with channel switching with proximity having a low correlation.
\end{abstract}

Keywords: Channel Switching, Engagement, Environment, Proximity

\section{Introduction}

The changing consumers' lifestyle, availability of global brands, technology intervention and new trends have led to increase in demand of simpler options, products which are of good quality and propositions driven by economy. This change has made retail channels to evolve to Branded grocery stores to meet the demands of consumers (Bsaikrushna, 2013).

The upgradation of retail structure in developing countries by coming in of branded store chains has led to the channel diversity. As previously there were very few branded chains and customers were compelled to buy from traditional grocery stores. Now, consumers are evaluating these new chains and then deciding whether to become loyal, switch to the old store from where they were purchasing earlier or start multi store purchase in their shopping. The importance of branded store chains is determined by the spent made by the customer in that particular store (Batislam \& Filiztekin, 2011).

Traditional grocery store provides easy accessibility and one-to-one service advantages as they are placed in area proximity locations. They are of great importance for those who do frequent / small amount of purchases, want social interactions and purchase on credit terms. On the other hand, branded grocery chains are self-service stores catering to the wide need sets of customers and fulfilling their solution by providing all required items under one roof.

\footnotetext{
${ }^{1}$ Muhammad Mubin Jaliawala is Regional Sales Manager, Shabbir Tiles \& Ceramics Limited Karachi, mmjaliawala@gmail.com

${ }^{2}$ Dr. Mustaghis-ur-Rahman is Dean, Faculty of Management Sciences, Indus University, Karachi, mustaghis@indus.edu.pk

\begin{tabular}{lll|c}
\hline JISR-MSSE & Volume 12 & Number 2 & July-December 2014 \\
\hline
\end{tabular}
} 
The unavailability of trustworthy facts does not allow companies in Pakistan to formulate fact based and focus oriented availability of product plans, channel oriented activities related to trade marketing and introducing incentives for traders. Retail audit data is provided by A.C. Nielsen but very few companies are taking advantage out of this facility and making right use of the data. This statement is also confirmed from different brand and marketing managers working of different companies. The rigorous market insights are hardly available in local companies which makes hard for companies to take business decisions (Baig, 2012).

The Next Generation of Retail Markets (2011) produced a report in collaboration with Deloitte and Panel Retail and reported that Pakistan is one of the ten rising economies having massive prospect for growth in the retail sector. This is because of few retail actors in the market, availability of variety and assortments of products, credit availability, regional development and multi pattern strategy. Pakistan Bureau of Statistics mentioned that Rs. 3.6 trillion (18\% of GDP) for the year 2011-12 is the total worth of retail. Furthermore, data reveals that there are approximately two million retail outlets in Pakistan. According to a study conducted for FMCG sector by 'Booz and Co' organized retailing (modern trade) penetration in India (5\%), China (20\%), Indonesia (30\%), Thailand (40\%), Malaysia (55\%), Taiwan (81\%) and USA $(85 \%)$ have increased significantly. The organized retailing in Pakistan is currently in single digit that shows ample prospect to pick up the format of our retail sector (Baig, 2012).

Muzondo and Mutandwa (2011) acknowledged that there are many models related to consumer buying behavior focusing on changing shopping trends, economies of scale, the consumer preferences and their behavior. Bokhari (2012) published that as per the Small and Medium Enterprise Development Authority (SMEDA), the retail market of Pakistan is estimated at $\$ 42$ billion out of which Karachi's only contribution is $40 \%$ of consumer business. It is estimated that around 125,000 retail outlets are present in the country out of which $94 \%$ are corner shops.

\subsection{Background of the Study}

Anecdotal evidence shows that people are more inclined towards buying from branded grocery chains than traditional grocery stores. This switching behavior has recently been observed in Pakistani retail industry. Hence this phenomenon will be studied here in context to local Pakistani environment.

Hassan and Rahman (2012) acknowledge that branded grocery chains are governed by selling variety of products where everyone can come and shop in despite of the status of social, background and income. This new retail addition in the infrastructure has made the retail industry more effective and efficient.

This research is beneficial specifically in the context of Pakistan on the subject of Switching behavior and has not been amply researched and studied before in this region. The direct stakeholders of our research are local marketers and retail organization, International / multinational marketing and advertising firms operating in Pakistan and Pakistani academic and business community at large. 


\subsection{Research Problem}

Consumer preference over one store type to another is now becoming a big challenge for not only present retailer base but also for the marketers who actually want their product to talk to consumer while placed on shelves. Grocery chains with high customers coming in and making monthly grocery purchases, having good image in the mind of customers and offering most variety are now becoming very important not only for the marketers but also are of great importance to the customers. Hence this phenomenon needs to be investigated in order to find out the determining factors for switching over from traditional grocery stores to branded grocery chains.

Hence the research question is:

What factors are responsible in promoting store switching behavior from traditional grocery stores to branded grocery chains in Karachi?

Whereas, main objectives of study are:

n To assess the level of switching over from traditional grocery stores to branded grocery chains.

n To find the determinants of switching over from traditional grocery stores to modern grocery chains.

\subsection{Scope of the Research}

The scope of study is limited to the respondents/subjects approached for the collection of data who come for monthly grocery purchase in Imtiaz, Chaseup and Naheed store in Karachi city of Pakistan. However, the applicability of the study can be extended to the people of other cities assuming the various homogeneous characteristics of Pakistani population as a whole.

\subsection{Limitations}

The limitations of this research are subject to the various reasons and circumstances which are mentioned below:

n This research is spreading over about 14 weeks which seems a time constraint.

n The geographical limitations set to conduct this study only include one city of Pakistan, narrows the scope and spectrum of this research.

\section{Literature Review}

The change in the structure of retail sector with the birth of MT stores is not a usual process. The introduction of new formats in retail is indicative of the increasingly role the retail is playing. Following three factors have helped to brought the change in retail structure (Shahabuddin, 2012):

\begin{tabular}{lll|l}
\hline JISR-MSSE & Volume 12 & Number 2 & July-December 2014 \\
\hline
\end{tabular}


n Media fragmentation: The increase of number of TV and radio channels on one side enhanced the awareness and knowledge levels among consumers but on the other side it is making very challenging and expensive to reach target audiences, even if the brand has ample marketing budgets.

n Variety: Cut throat competition is being experienced by all categories different choices are available for consumers to pick and choose from the multiple local and international brands.

n Shopping experience: Now-a-days shopping experience has become very important for consumers. Retailers can easily show their power over consumer choice and turn themselves into brand.

Cohen and Jones (2009) stated that segments in the retail market are discounter, mass merchandiser, department store and luxury store based on the target income group and ego involvement. Prior to this the segmentation was done as promotional store, moderate price store and luxury store for low income shoppers, middle income shoppers and high income shoppers respectively.

As per AC Nielsen the retail industry in Pakistan has been divided into: branded grocery store / super store, general store, medical / general store, exclusive medical store, hotel / eating places, kiryana store, pan / cigarette shop, corner store, bakery, utility stores and top end retail stores. These classifications are done on the basis of location, area or size of the shop, availability of product assortments and variety and category being handled by the store.

Branded grocery store stores as defined by AC Nielsen are a predominantly large store with selling area of more than 100 square feet, having two or more cash machines. They are normally based on self services but mixed type of services can be in place as well. These are modern shops, very organized and with a wider assortment of food, drug and other products like: households, personal, gifts, kitchen utensils, small electrical appliances, cosmetics, detergents, souvenirs and clothes. Branded grocery store consists of supermarkets and hypermarkets that retail mainly Fast Moving Consumer Goods (FMCGs). It is the organized retail and format is gaining popularity and importance day by day (Equitymaster, 2012).

The evolution of branded grocery store is possible due to changing consumers' needs and demands. More consumers are shifting to branded grocery store stores hence leading to increase in number of branded grocery store stores in Pakistan. As per the study of A.C. Nielsen, the one-fifth of the population in India is buying groceries habitually from branded grocery store stores. In India, the penetration of branded grocery store will be three times in the next five years by 2018 (15\% to $20 \%$ ). With increase choices of the brands, liberty to look through the merchandise and the introduction of saving packs and promotion, the branded grocery store consumers perceive their experience as a smarter option of buying things. Usually the branded grocery store consumers are coming along with relatives and acquaintances and they do not prefer to come in isolation (Bsaikrushna, 2013).

\subsection{Factors Affecting Store Choice}

Muzondo and Mutandwa (2011) mentioned that there are implications of Marketing's 7Ps on Consumer behavior. "One study has determined 10 attributes of store choice that can impact 
the decision and are location, nature and quality of assortment, price, advertising and promotion, sales personnel, services offered, physical store attributes nature of store clientele, store atmosphere, and post transaction service and satisfaction".

Euromonitor (1986) found 21 items important for a branded grocery store. These are clean and hygienic, cheap or low prices, store layout, extensive range, good parking, good value, quality of foods, own label products, opens late, fresh fish, good fruit, carry out service, selection of frozen food, spacious, easy walking distance, good fresh meat, quick service of checking out, presence of bakery inside the store, refrigerated food items, quality vegetables, and other factors. In 1998 Mintel found that there are 13 important factors that influence consumer choice of store for main grocery shopping in Britain.

Promsaad and Suwanvijit (2009) in a research conducted for Thailand found out that the behavior of purchasing from branded grocery chain is evident in market place. Hassan and Rahman (2012) found out that shopping activities are to fulfill household and economic needs of consumers. According to Bitta and Loudon (1993), following are the attributes that can induce channel switching from traditional grocery store to braded grocery chains and are defined as follows:

Store location: According to Bitta and Loudon (1993) the store location has an impact on store importance. Consumers will purchase from the store if the store location is closer to them. Thomas (2012) mentioned that the store location is everything behind the success of a retail store. It should be located near or within a neighborhood because consumers now a days think of convenience more than the prices because of inflation in fuel and gasoline products rates. The already existed store in a building is more preferred with high visibility preferably near a popular area.

The store location, intercity choice and intracity choice involve:

Store design and physical facilities: The Design features include layout, placements in the aisle and width, architecture as well as physical facilities established by Bitta and Loudon (1993).

Customer services: Hassan and Rahman (2012) explain that grocery shopping is a low involvement activity hence requires a great deal to entice customers with the shopping experience by giving positive feelings to them. Shopping experience is not just about selecting and buying products from shelves, service has also become part of core product with shopping. This factor is considered to be a tough one because of increasing competition diversity in the retail sector. Entertainment now has been made part of the experience to motivate shoppers to extend shopping duration. Hence the service is critical to increase product satisfaction and convenience, provide special benefits.

\subsection{Conceptual Framework}

From the literature three variables have been derived i.e. proximity, engagement and environment considering the present time frame and dynamics of retail. Their relationship with the dependent variable channel switching will be tested out in the study.

\begin{tabular}{lll|l}
\hline JISR-MSSE & Volume 12 & Number 2
\end{tabular}




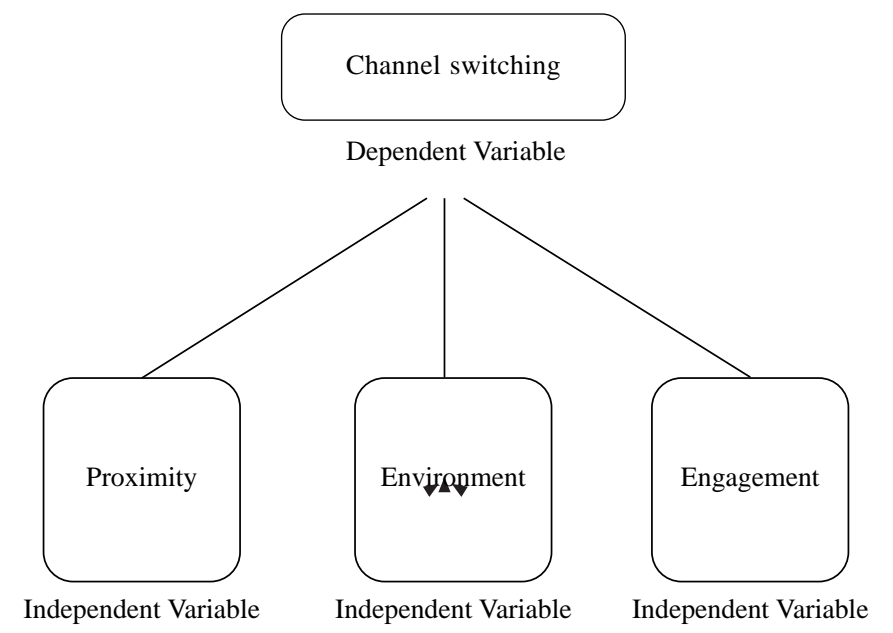

\section{Dependent Variable}

\section{Channel Switching}

n From traditional store to branded grocery chains.

\section{Independent Variables:}

\section{Proximity}

n The closer the customer, the higher the likelihood of purchase from store. It includes easy access and safe locality.

\section{Environment}

n Layouts, lightening, washrooms, elevators, air-conditioning, ATM, easy entry and exit points, quality products availability, neat and clean, spacious and efficient checkout system.

\section{Engagement}

n Entertainment, store interception, offerings, connecting with the customers making them feel engaged and motivated.

\subsection{Hypotheses}

$\mathrm{H}_{1}$ : Proximity of the retail stores is a determining factor for switching

$\mathrm{H}_{2}$ : Retail stores' environment is an important factor for shopping from branded grocery chains

H3: Retail stores engaging characteristic is making customers to shift from traditional grocery store

\begin{tabular}{l|llll}
\hline 6 & July-December 2014 & Volume 12 & Number 2 & JISR-MSSE
\end{tabular}




\section{Research Methodology}

This study is quantitative in nature and encompasses the use of positivist paradigm. Deductive approach has been used. Survey method is opted as a part of strategy in this research. As per the time horizon it's a cross sectional study. Since the topic requires finding out factors that leads to store switching in Karachi, close ended questionnaire are used as research instruments. A detailed analysis has been performed using SPSS.

\subsection{Population and Samples}

The population of this study consists of Branded grocery chains of Karachi. The study is conducted in Karachi top three chains like Imtiaz Super Store ,Naheed Super Store and Chase up Departmental Store located in posh areas like Shara-e-Faisal, Bahadurabad and North Nazimabad. There are total 3 branded grocery chains. Males and Females have been targeted they can be either married or un married.

\subsection{Sampling Technique}

In this study, the sample size has been calculated by using the Confidence Interval Approach. It is determined by the help of a statistical formulae applied in Confidence Interval Approach at $\pm 10 \%$ margin of error and $95 \%$ level of confidence for a large population size, which equals to 97 (Rea \& Parker 2005, pp. 85-95). However, a sample size of 105 for the convenience of proportionate division of the sample size amongst the three selected stores i.e. Imtiaz, Naheed and Chase up. Hence, the individual sample size of each store will be equal to 35 . The following criteria has been used for selecting respondents in this study: participants must have started monthly grocery purchase since last one year

The sample has been collected using random sampling approach under non-probability quota sampling criteria. The reason for choosing this sampling method for study is that each stores is having equal weightage in response rate

\subsection{Research Instrument}

In this research, questionnaire has been used as research instrument. The reason for choosing survey questionnaire is that, in comparison to interviews, it is more cost-effective and suitable for studies having a large sample size. By using questionnaire survey, the researcher can analyze and interpret responses easily as the responses can be analyzed through different statistical software. The chances of biasness are comparatively fewer and results are more authenticated than interview responses.

The questionnaire is divided into two parts the section A has questions based on nominal scale about demographics. These are 4 in total. The second section has 14 statements about the three independent and one dependent variables based on LIKERT scale ranging from 1 to 5.1 is for strongly disagree, 2 is for Disagree, 3 is for Neutral, 4 is for Agree and 5 is for Strongly agree. The questions (close ended) will be asked from the selected sample. The dependent variable Channel switching is asked using two statements. For the three independent variables, seven statements are generated for environment, three statements for engagement and two statements for proximity.

\begin{tabular}{lll|l}
\hline JISR-MSSE & Volume 12 & Number 2 & July-December 2014
\end{tabular}




\subsection{Data Collection}

Data is collected from the customers who were coming in and were buying their monthly grocery from branded grocery chains as mentioned earlier. Population is consisted of males and females coming and shopping for monthly grocery at Branded grocery chains stores. Research is self administered by the researcher by intercepting with the customers directly. To control non response or any other issue, few extra questionnaires were filled out to avoid confusion

\section{Data Analysis and Interpretation}

To analyze data, SPSS Statistics 17.0 has been used to carry out detailed analysis ranging from reliability, demographics, descriptive, correlation and ANOVA.

\subsection{Reliablity and Validity}

\subsubsection{Reliability}

It measures the extent to which it is without bias an hence ensures consistent measurement across the various items like channel switching, location, environment and engagement in the instrument. To test reliability inter-item consistency reliability has been used to test the consistency of respondents' answer to all the items in a measure. Hence Cronbach's coefficient alpha has been used for multipoint scaled items related to dependent and independent variables.

\begin{tabular}{cc}
\hline Reliability Statistics & \\
\hline Cronbach's Alpha & N of Items \\
\hline .773 & 4 \\
\hline
\end{tabular}

From the above-mentioned reliability statistics, it is evident that the obtained value of Cronbach's alpha for the scale is 0.77 . The desired value should be atleast 0.7 . Hence the level of inter-item consistency reliability of the statistical data is proved to be acceptable.

\subsubsection{Validity}

The questionnaire is developed with the measure of relevant constructs. To measure the Construct Validity, a few modifications were made consistent with the specific features related to our research study. The questionnaire consisted of four variables: Channel switching (2 items), Proximity (2 items), Engagement ( 3 items) and Environment ( 7 items). Before deciding the scale measures, a senior professor and marketing experts were advised to establish the face validity.

\subsection{Demographic Analysis}

As per the data collected the age of the respondents are under below percentages mentioned in the table. It can be seen here that $8 \%$ of the respondents are in the age bracket of 18 to 24 years while $52 \%$ are between 25 to 30 years while the age limit from 31 years and above are $40 \%$

\begin{tabular}{l|llll}
\hline 8 & July-December 2014 & Volume 12 & Number 2 & JISR-MSSE
\end{tabular}




\begin{tabular}{llrrrr}
\hline Age & & & & \\
& & Frequency & Percent & Valid Percent & $\begin{array}{r}\text { Cumulative } \\
\text { Percent }\end{array}$ \\
\hline Valid & $18-24$ & 8 & 7.6 & 7.6 & 7.6 \\
& $25-30$ & 55 & 52.4 & 52.4 & 60.0 \\
& 31 and above & 42 & 40.0 & 40.0 & 100.0 \\
& Total & 105 & 100.0 & 100.0 & \\
\hline
\end{tabular}

Out of the total 105 respondents, $46 \%$ are male while the remaining $54 \%$ are females.

\begin{tabular}{llrrrr}
\hline Gender & & & & \\
\hline \multirow{2}{*}{ Valid } & Male & 48 & 45.7 & 45.7 & 45.7 \\
& Female & 57 & 54.3 & 54.3 & 100.0 \\
& Total & 105 & 100.0 & 100.0 & \\
\hline
\end{tabular}

As the data is collected equally from all the stores, the percentage contribution of responses from all is $33 \%$

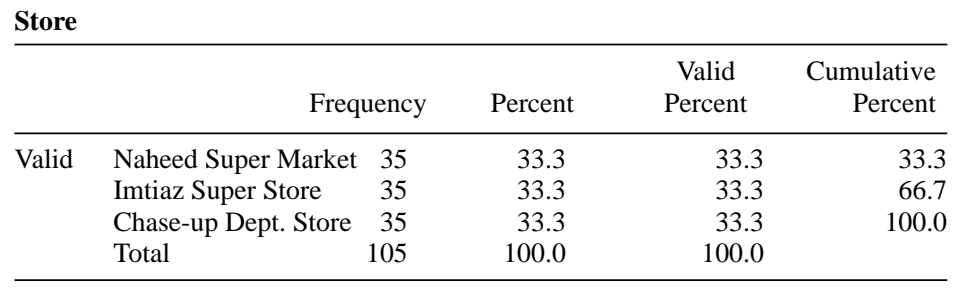

With reference to buying duration it is found out from the data that $10 \%$ have initially started buying since 1 to 3 months period from branded grocery stores, 29\% are buying since 6 months or below and $61 \%$ are buying since 7 to 12 months.

\begin{tabular}{|c|c|c|c|c|c|}
\hline & & Frequency & Percent & $\begin{array}{c}\text { Valid } \\
\text { Percent }\end{array}$ & $\begin{array}{r}\text { Cumulative } \\
\text { Percent }\end{array}$ \\
\hline \multirow[t]{4}{*}{ Valid } & 1-3 months & 10 & 9.5 & 9.5 & 9.5 \\
\hline & 4-6 month & 31 & 29.5 & 29.5 & 39.0 \\
\hline & $7-12$ months & 64 & 61.0 & 61.0 & 100.0 \\
\hline & Total & 105 & 100.0 & 100.0 & \\
\hline
\end{tabular}

\subsection{Descriptive Analysis}

The statistics mentioned below show that all the variables are tapped on a 5-point Likert scale. As the mean value is above 4 for all the variables showing that the all the responses are seriously taking these variables inconsideration for switching from traditional grocery stores to branded grocery chains in Karachi. Standard deviations are close to 0.6 showing on average deviation from they mean value or simply how deviated the responses are on variables from their mean value.

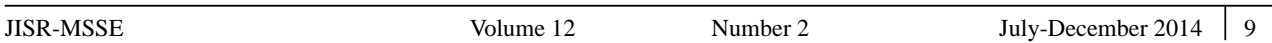




\begin{tabular}{lrrrrrr}
\multicolumn{1}{l}{ Descriptive Statistics } \\
\hline & N & Range & Minimum & Maximum & Mean & $\begin{array}{c}\text { Std. } \\
\text { Deviation }\end{array}$ \\
\hline \multicolumn{2}{l}{ Statistic } & Statistic & Statistic & Statistic & Statistic & Statistic \\
\hline Location & 105 & 3.50 & 1.50 & 5.00 & 4.0429 & .62832 \\
Environment & 105 & 2.43 & 2.57 & 5.00 & 4.1537 & .41209 \\
Engagement & 105 & 3.67 & 1.33 & 5.00 & 4.0921 & .64797 \\
Channel Switching & 105 & 3.67 & 1.33 & 5.00 & 4.0921 & .64797 \\
Valid N (listwise) & 105 & & & & & \\
\hline
\end{tabular}

\subsubsection{Proximity}

The results are the summation of the variables from the five point Likert (non-comparative) scale with ' 1 ' being 'Strongly Disagree' rating and ' 5 ' being Strongly Agree rating from any respondent. The Proximity mean scores are 4.04 which shows that the research participants have shown positive opinion about Proximity and are away from mean ' 3 '. While Standard deviations are close to ' 0.62 ' showing an average deviation from their mean value or simply how deviated responses are on variables from their mean value.

\subsubsection{Environment}

The results are the summation of the variables from the five point Likert (non-comparative) scale with ' 1 ' being 'Strongly Disagree' rating and ' 5 ' being 'Strongly Agree' rating from any respondent. The Proximity mean scores are 4.15 which shows that the research participants have shown positive opinion about Environment and are away from mean ' 3 '. While Standard deviations are close to ' 0.41 ' showing an average deviation from their mean value or simply how deviated responses are on variables from their mean value.

\subsubsection{Engagement}

The results are the summation of the variables from the five point Likert (non-comparative) scale with ' 1 ' being 'Strongly Disagree' rating and ' 5 ' being 'Strongly Agree' rating from any respondent. The Proximity mean scores are 4.09 which shows that the research participants have shown positive opinion about Environment and are away from mean ' 3 '. While Standard deviations are close to ' 0.64 ' showing an average deviation from their mean value or simply how deviated responses are on variables from their mean value

\subsubsection{Channel Switching}

The results are the summation of the variables from the five point Likert (non-comparative) scale with ' 1 ' being 'Strongly Disagree' rating and ' 5 ' being 'Strongly Agree' rating from any respondent. The Proximity mean scores are 4.24 which shows that the research participants have shown positive opinion about Environment and are away from mean ' 3 '. While Standard deviations are close to ' 0.65 ' showing an average deviation from their mean value or simply how deviated responses are on variables from their mean value 


\subsection{Correlation Testing}

\begin{tabular}{|c|c|c|c|c|c|}
\hline & & Proximity & Environment & Engagement & $\begin{array}{r}\text { Cumulative } \\
\text { Percent }\end{array}$ \\
\hline \multirow[t]{3}{*}{ Proximity } & Pearson Correlation & 1 & $.314 * *$ & $.356^{* *} *$ & $.233^{*}$ \\
\hline & Sig. (2-tailed) & & .001 & .000 & .017 \\
\hline & $\mathrm{N}$ & 105 & 105 & 105 & 105 \\
\hline \multirow[t]{3}{*}{ Environment } & Pearson Correlation & $.314 * *$ & 1 & $.687 * *$ & $.730 * *$ \\
\hline & Sig. (2-tailed) & .001 & & .000 & .000 \\
\hline & $\mathrm{N}$ & 105 & 105 & 105 & 105 \\
\hline \multirow{3}{*}{ Engagement } & Pearson Correlation & $.356 * *$ & $.687 * *$ & 1 & $.638 * *$ \\
\hline & Sig. (2-tailed) & .000 & .000 & & .000 \\
\hline & $\mathrm{N}$ & 105 & 105 & 105 & 105 \\
\hline \multicolumn{6}{|l|}{ Channel } \\
\hline \multirow[t]{3}{*}{ Switching } & Pearson Correlation & $.233 *$ & $.730 * *$ & $.638 * *$ & 1 \\
\hline & Sig. (2-tailed) & .017 & .000 & .000 & \\
\hline & $\mathrm{N}$ & 105 & 105 & 105 & 105 \\
\hline
\end{tabular}

**. Correlation is significant at the 0.01 level (2-tailed).

*. Correlation is significant at the 0.05 level (2-tailed).

\subsubsection{Proximity and Channel Switching}

This shows that there is a weak relationship between these two variables. This means that changes in one variable is not correlated with changes in the second variable. But the relationship between these two variable is positive. The Sig. (2-tailed) value is 0.17 which is less than 0.5 showing an existence of relationship between these two variables.

4.4.2 Environment and Channel Switching

This shows that there is a strong relationship between Environment and Channel Switching. This means that changes in one variable are strongly correlated with changes in the second variable. For this reason, it can be concluded that there is a strong relationship between them.

\subsubsection{Engagaement and Channel Switching}

This shows that there is a strong relationship between Engagement and Channel Switching which means that changes in one variable are strongly correlated with changes in the second variable. For this reason, we can conclude that there is a strong relationship between them.

\subsection{Regression Analysis}

The value of $\mathrm{R}$ is 0.755 and it explains high degree of correlation between these variables. In this case, 57\% of channel switching is explained by Proximity, Environment and Engagement. 


\begin{tabular}{|c|c|c|c|c|c|c|}
\hline \multicolumn{2}{|l|}{ Model } & $\mathrm{R}$ & R Square & & $\begin{array}{l}\text { isted } \\
\text { juare }\end{array}$ & $\begin{array}{l}\text { Std. Error of } \\
\text { the Estimate }\end{array}$ \\
\hline \multicolumn{2}{|l|}{1} & $.755^{\mathrm{a}}$ & \multicolumn{2}{|l|}{.569} & .557 & .43337 \\
\hline \multicolumn{7}{|c|}{ a. Predictors: (Constant), Engagement, Proximity, Environment } \\
\hline \multicolumn{7}{|c|}{ ANOVA $^{b}$} \\
\hline \multicolumn{2}{|l|}{ Model } & $\begin{array}{l}\text { Sum of } \\
\text { Squares }\end{array}$ & $\mathrm{df}$ & $\begin{array}{l}\text { Mean } \\
\text { Square }\end{array}$ & $\mathrm{F}$ & Sig. \\
\hline \multirow[t]{3}{*}{1} & Regression & 25.089 & 3 & 8.363 & 44.529 & $.000 \mathrm{a}$ \\
\hline & Residual & 18.969 & 101 & .188 & & \\
\hline & Total & 44.057 & 104 & & & \\
\hline \multicolumn{7}{|c|}{ a. Predictors: (Constant), Engagement, Proximity, Environment } \\
\hline \multicolumn{7}{|c|}{ b. Dependent Variable: ChannelSwitching } \\
\hline \multicolumn{7}{|c|}{ Coefficients $^{\mathrm{a}}$} \\
\hline & & \multicolumn{2}{|c|}{$\begin{array}{l}\text { Unstandardized } \\
\text { Coefficients }\end{array}$} & $\begin{array}{l}\text { tandardized } \\
\text { Coefficients }\end{array}$ & & \\
\hline \multicolumn{2}{|l|}{ Model } & B & Std. Error & Beta & $\mathrm{t}$ & Sig. \\
\hline \multirow[t]{3}{*}{1} & Regression & 25.089 & 3 & 8.363 & 44.529 & $.000 \mathrm{a}$ \\
\hline & Residual & 18.969 & 101 & .188 & & \\
\hline & Total & 44.057 & 104 & & & \\
\hline
\end{tabular}

a. Dependent Variable: ChannelSwitching

\section{Results and Discussion}

The study attempted to evaluate branded grocery chains in Karachi to find out the consumer switching behavior from traditional grocery stores to branded grocery chains. It is learned from the analysis that factors affecting consumer switching may vary from one consumer to the other but on mean terms it can be seen that the Proximity, Engagement and Environment are positively correlated with the switching behavior of a consumer. According to the data analyzed, all the three hypothesis hold true hence null hypothesis are approved. To ascertain level of switching from Traditional grocery stores to Branded grocery chains it can be seen from the results that $90 \%$ of the respondents have been buying since 4 months and above.

With reference to Environment companies can also look into options of providing comfort to their customers through different setup creation inside store with branded themes to endorse the brand as well as the factor which is important in inducing store switching. Stores can be provided ACs, ATMs, Credit card facility etc and in return the store can provide the company with branding options. This will help stores to improve environment and in return companies can place their brand prominently in the stores

For engagement, marketers should have promotions pertains to particular store where consumers can be engaged with the brand through various one to one interaction models.

Proximity is important too. People prefer stores which are located within the city or closer to the densely populated sections. This helps consumers to go in easily and shop from the store at ease.

\begin{tabular}{l|lll}
\hline 12 & July-December 2014 & Volume 12 & Number 2
\end{tabular}




\section{Conclusion and Recommendations}

The findings of the study explained the previous study by Bitta and Loudon (1993) and suggest that strong correlation exists between Channel Switching, Proximity, Location, Engagement and Environment. Environment among other factors had the highest correlation with Channel Switching from traditional grocery stores to branded grocery chains. This shows that if environment of the store is enhanced, it will result in more people switching from traditional grocery stores to branded grocery chains in Karachi. Engagement is the second variable which has shown strong correlation after Environment.

However, almost negligible correlation exists between Switching behavior and Proximity of a store. This suggest that in these days no matter the where ever the store is located, consumers will come and visit if it is offering good environment and consumer engagement activites.

This study shows that the three independent variables (Proximity, Engagement and Environment) are correlated with each other. This concludes that in order for the marketing professionals to gain more of a millage on their store investments should focus on those stores which is providing these three factors to the consumers who are coming in for the monthly grocery shopping purchase. It further facilitate the store managers to organize the independent variables in such a manner that it focuses more on Environment then Engagement and then Location. As this gives the variance of $57 \%$ as explained by these variables and $56 \%$ of Channel Switching variance of the population. The finding of the research suggest a few implication for the consumers, marketers and retail managers.

The relationships explored provide a wider insight over the areas which must be explored further to induce consumer switching from traditional grocery stores to branded grocery chains. The myth of Proximity of a store as the witching factor has proved to be wrong. This implies that consumer channel switching must consider the Engagement and Environment as the major influencers of channel switching

\section{Areas of Further Research}

Retail industry is considered to be growing industry and has a lot of challenges and risks. Retail management has to devise certain strategy to make ure that the store opened is a success. The relationship of Consumer channel switching with these variables may get affected due to increase in online shopping these days. Future researchers may incorporate this variable in their studies as when the online shopping is on its rise, then engagement and environment becomes weak and vice versa.

\section{References}

Armstrong, G. \& Kotler, P. (2007). Principles of Marketing (12th ed.). New York: Prentice Hall.

Batislam, E. P., \& Filiztekin, A. (2011). Channel switching behavior during the modernization of grocery retailing in Turkey. Retrieved from http://research.sabanciuniv.edu/17090/

\begin{tabular}{lll|l}
\hline JISR-MSSE & Volume 12 & Number 2 & July-December 2014 \\
\hline
\end{tabular}


Bitta, A. D., \& Loudon, D. (1993). Consumer Behavior (4th ed.). New York: McGraw-Hill.

Bsaikrushna. (2013). The modern trade consumer in India. Retrieved from http://brandalyzer.wordpress.com/2013/01/05/the-modern-trade-consumer-in-india/

Baig, S. (2012). Future of retailing in Pakistan, Business Recorder. Retrieved from http://www.brecorder.com/supplements/:36th-fpcci-export-awards-2011-

Bokhari, A (2012). Preference for local store, Dawn. Retrieved from http://www.dawn.com/news/693583/preference-for-local-stores

Cohen, A. I., \& Jones, L. A. (2009). Brand marketing in the new retail environment, Harvard Business Review.

Equitymaster. (2012). Is modern trade the future growth driver for FMCG?. Retrieved from http://www.equitymaster.com/detail.asp?date=10/05/2012andstory=2andtitle=Is-

Hassan, H., \& Rahman, M. S. (2012). Extended shopping experiences in hypermarket, Asian Social Science, 8(11). doi:10.1108/10610420710763912

Hassan, H. , \& Rahman, M. S. (2012). The Impact of Hypermarket Corporate Brand Extensions on Brand Personality: A Conceptual Analysis of Malaysian Market, International Journal of Business and Management, 7(12). doi: 10.5539/ijbm.v7n12p138

Kanuk, L. L., \& Schiffman, L. G. (2007). Consumer Behavior (9th ed.). New Jersey: Pearson Prentice Hall.

Massad, V. J., Nein, M. B., \& Tucker, J. M. (2011). The Wheel of Retailing revisited: toward a Wheel of e-tailing, Journal of Management and Marketing Research, 8(1). Retrieved from http://connection.ebscohost.com/c/articles/74534617/wheel-retailing-revisitedtoward-a-wheel-e-tailing

Muzondo, N., \& Mutandwa, E. (2011). The seven Ps of Marketing and choice of main grocery store in a hyperinflationary economy, Contemporary Marketing Review, 1(9), 1-18. Retrieved from http://www.businessjournalz.org/articlepdf/cmr1505n19.pdf

Promsaad, S., \& Suwanvijit, W. (2009). The Insight Study of Consumer Life-styles and Purchasing Behaviors in Songkla Province - Thailand, International Journal of Marketing Studies, 1(2). doi: 10.5539/ijms.v1n2p66

Shahabuddin, A. (2012). Selling the experience. The Aurora. Retrieved from http://aurora.dawn.com/2012/01/03/modern-retail/

Thomas, J. (2012). How to Open a Grocery Store, Life123 Inc. Retrieved from http://www.life123.com/career-money/new-business/retail-store/how-to-open-a-grocerystore.shtml 


\title{
Questionnaire
}

Dear Respondent: This survey is carried out to examine factors pertaining to store switching behavior from traditional trade to modern trade. The research is conducted at an academic level by the student of SZABIST, Karachi, as part of the partial fulfillment of the IS. Your participation in this regard is highly appreciated. Confidentiality of the data will be maintained This questionnaire is valid for those who have been switched to Branded grocery chains in a span of last one year

\section{Section A}

1. Age:

$18-24$

$25-30$

31 and above

2. Gender:

Male

Female

3. $\square$ Monthly Grocery Purchase location:

\author{
Naheed \\ Super Market
}

Imtiaz Super Market

Chaseup Dept store

4. Approximately how long you have been buying grocery or ration from a Modern Trade store?
$1-3$
$4-6$
$7-12$
More than one year

\section{Section B}

\begin{tabular}{lccccc}
\hline Please tick one option from the given table & 1 & 2 & 3 & 4 & 5 \\
\hline & $\begin{array}{l}\text { Strongly } \\
\text { Disagree }\end{array}$ & Disagree & Neutral & Agree & $\begin{array}{c}\text { Strongly } \\
\text { Agree }\end{array}$ \\
\hline
\end{tabular}

1. I have switched over from traditional grocery stores to the branded chain because of easy accesses to these stores

2. I prefer buying from a branded grocery chain located in good and safe locality

3. Branded grocery chains have facilities like ATM, Credit card acceptance which is not in case of traditional grocery stores.

4. Branded chains have easy entry and exit points that make me to go and do monthly grocery purchase from there.

5. I enjoy monthly grocery shopping if I have been entertained during the stay in branded grocery chains.

\begin{tabular}{llll|l}
\hline JISR-MSSE & Volume 12 & Number 2 & July-December 2014 & 15
\end{tabular} 


\begin{tabular}{|c|c|c|c|c|c|c|}
\hline & Please tick one option from the given table & 1 & 2 & 3 & 4 & 5 \\
\hline & & $\begin{array}{l}\text { Strongly } \\
\text { Disagree }\end{array}$ & Disagree & Neutral & Agree & $\begin{array}{l}\text { Strongly } \\
\text { Agree }\end{array}$ \\
\hline 6. & $\begin{array}{l}\text { I like someone can guide me during shopping } \\
\text { as it increases the likelihood of purchasing } \\
\text { particular product - store interception }\end{array}$ & & & & & \\
\hline 7. & $\begin{array}{l}\text { I will not switch to traditional grocery store } \\
\text { because of convenience and comfort I have } \\
\text { in branded grocery chains }\end{array}$ & & & & & \\
\hline 8. & $\begin{array}{l}\text { Branded grocery chains is the place where } \\
\text { I would love to do my grocery from every } \\
\text { month }\end{array}$ & & & & & \\
\hline 9. & $\begin{array}{l}\text { Availability of quality products in branded } \\
\text { grocery chains has led me to switch from } \\
\text { traditional grocery stores }\end{array}$ & & & & & \\
\hline 10. & $\begin{array}{l}\text { Clean environment of the branded grocery } \\
\text { chains has made me to come here every } \\
\text { month for grocery }\end{array}$ & & & & & \\
\hline 11. & $\begin{array}{l}\text { Convenient store lay out is what I like about } \\
\text { branded grocery chains }\end{array}$ & & & & & \\
\hline 12. & $\begin{array}{l}\text { Consumer offerings have always attracted } \\
\text { me in branded grocery chains which are not } \\
\text { available in traditional grocery stores }\end{array}$ & & & & & \\
\hline 13. & $\begin{array}{l}\text { Branded grocery chains are spacious as } \\
\text { compared to traditional grocery stores }\end{array}$ & & & & & \\
\hline 14. & $\begin{array}{l}\text { Branded grocery chains has efficient and } \\
\text { quick checkout system while traditional } \\
\text { grocery stores lack this facility }\end{array}$ & & & & & \\
\hline
\end{tabular}

